\title{
Effects of deficit irrigation on yield and water use of grown cucumbers in Saudi Arabia
}

\author{
A. M. Alomran \& I. I. Luki \\ Department of Soil Science, College of Food Sciences and Agricultural, \\ King Saud University, Riyadh, Saudi Arabia
}

\begin{abstract}
Deficit irrigation can play an important role in increasing water use efficiency (WUE) and reduced amount of irrigation. Deficit irrigation generally refers to fully irrigated crops where water is reduced or withheld during certain growth stages. In this study, a series of greenhouse and open field experiments were conducted using a deficit irrigation program on cucumber crops under drip irrigation during 2007-2010 growing seasons. The layout of the experiment was a completely randomized design with four replicates. Irrigation treatments consisted of five levels of ETc $(30,40,60,80$, and 100\% of ETc) in addition to traditional practice by farmers. At 60 and $80 \%$ treatments, deficit irrigation tested at different growth stages (development, med, and late stages of the growth) for a total of 14 treatments at each experiment. The maximum amount of water applied to the crop was $332 \mathrm{~mm}$ for the $100 \%$ ETc treatment while the minimum water applied was $100 \mathrm{~mm}$ for $30 \%$ Etc treatment, and $600 \mathrm{~mm}$ for traditional practice by the farmers in the region. The calculated ETc ranged from between 95 and $316 \mathrm{~mm}$ for the different treatments. The objective of the study was to determine the crop water requirements in both the open field and greenhouse and calculate crop response factor (ky) and WUE of cucumber crop using a deficit irrigation program at different stages of growth. Results indicated that a cucumber could stand the shortage of water during the growth and crop response $(\mathrm{Ky})$ values ranging between 0.7 and 0.98 . However, the amount of water used was much lower than that of the traditional method used by farmers in the region. Water use efficiency (WUE) and water productivity (WP) values increased when water amounts decreased with the exception of the traditional irrigation; these values decreased to 45.6 and $24 \mathrm{~kg} / \mathrm{m}^{3}$, respectively. The highest values at much stressed treatment $30 \%$ ETc.
\end{abstract}

Keywords: deficit irrigation, crop response factor, water use efficiency, drip irrigation, crop water requirement. 


\section{Introduction}

Water scarcity and continuous decreases in water resources coupled with an increasing demand for water in agriculture and other sectors has forced farmers and governments to alter their irrigation practices and water management attempting to water saving practice and management. In Saudi Arabia, both farmers and governmental agencies start changing the irrigation strategies from an open field to greenhouse using surface and subsurface drip irrigation. One of important method to save irrigation water and increase WUE is deficit irrigation (DI) [1-3], in which crops deliberately allowed some degree of deficit irrigation through the whole growth stage or at certain stages of the growth [1]. The adoption of deficit irrigation required the knowledge of crop evapotranspiration (ETc), crop response to water deficit, critical stages of growth under water deficit and economic impacts of yield reduction [4]. Agele et al. [5] concluded that seasonal crop ET values were greater during reproduction growth stage in the crop. Amer et al. [6] concluded that the cucumber yield significantly decreased in linear relationship with increasing water deficit. However, no significant changed when water applied above $100 \% \mathrm{ETc}$. Mao et al. [7] reported on their study about the effect of deficit irrigation on yield and water use of greenhouse grown cucumber in China that the WUE decreased when increase the irrigation water applied from stem fruiting to the end.

The deficit irrigation strategy has received very little attention in agricultural sector in Saudi Arabia therefore; the main objectives of this study were to determine the water requirement for cucumber grown under drip irrigation system in a greenhouse in Saudi Arabia conditions, study the effect of deficit irrigation on cucumber fruit, and water use efficiency.

\section{Materials and methods}

Field experiments were carried out at the greenhouse complex of Almohous Farm, $120 \mathrm{~km}$ northwest of Riyadh, Saudi Arabia (altitude: $722 \mathrm{~m}$ above sea level, latitude: $25^{\circ} 17^{\prime} 40^{\prime \prime} \mathrm{N}$ and longitude: $45^{\circ} 52^{\prime} 55^{\prime \prime} \mathrm{E}$ ), from February, 2007 till April, 2011 for a total of 12 experiments at different time of the year. Soil salinity was determined before the trial set and at the end of the crop cycle, each $30-50 \mathrm{~cm}$ depth at the root level. Selected properties of the soil and irrigation water were determined by standard procedure [8]. The $\mathrm{pH}$ and $\mathrm{CaCO}_{3}$ of the soil were 7.9 , and $18 \%$, however sand $\%$ and clay $\%$ were $84 \%$ and $10 \%$, respectively. The layout of the experiment was completely randomized design with four replicates. The irrigation treatments consist of four level of ETc $(40,60,80$, and $100 \%$ ) in addition to the tradition farmers drip irrigation. At 60 and $80 \%$ treatments, the deficits irrigation were tested for different growth stages (development, mid., and late growth stages) for total of 12 treatments at each run of experiment. The main irrigation line was $63 \mathrm{~mm}$, and the sub mainlines were $16 \mathrm{~mm}$ in diameter; the length of sub main lines were $17 \mathrm{~m}$ for each line and emitters built at $0.5 \mathrm{~m}$ spacing with distance between rows of $1 \mathrm{~m}$. Furthermore, 
gauges were installed for measuring the amount of applied water for each treatment.

\section{Results and discussion}

Water use efficiency (WUE) and water productivity (WP) represent the productivity of water related to yield. The $T_{4}-80$ treatment was found to be the best treatment in terms of yield and water productivity, these values were $14.2 \mathrm{~kg} / \mathrm{m}^{2}$ and $48 \mathrm{~kg} / \mathrm{m}^{3}$ (Table 1); however the tradition irrigation led to lower water productivity. Moreover, decreasing irrigation water to $40 \%$ ET caused very high water productivity however decreases the final yield. Generally, the water use efficiency (WUE) and water productivity (WP) values increased when water amount decreased, these decreased values were 74.0 and $61.9 \mathrm{~kg} / \mathrm{m}^{3}$, and 48.9 and $42.3 \mathrm{~kg} / \mathrm{m}^{3}$ for WUE and WP in $\mathrm{T}_{12}$ and $\mathrm{T}_{1}$ treatments respectively, similar results were reported by [9-11]. The results of cucumber yield for different treatments (Table 1) indicated that the highest yield was obtained in the

Table 1: $\quad$ Yield, evapotranspiration (ETc), applied water (AW), water use efficiency (WUE) and water productivity (WP) as affected by deficit irrigation treatments at different growth stages of cucumber.

\begin{tabular}{|c|c|c|c|c|c|c|c|}
\hline Treatments & $\begin{array}{c}\text { Average } \\
\text { days per } \\
\text { season }\end{array}$ & $\begin{array}{c}\text { Yield } \\
\mathrm{kg} \mathrm{m}^{-2}\end{array}$ & $\begin{array}{c}\mathrm{ETc} \\
\mathrm{mm}\end{array}$ & $\begin{array}{c}\mathrm{AW} \\
\mathrm{mm}\end{array}$ & $\begin{array}{c}\mathrm{AW} \\
\mathrm{mm} \\
\mathrm{day}^{-1}\end{array}$ & $\begin{array}{c}\mathrm{WUE} \\
\mathrm{kgm}^{-3}\end{array}$ & $\begin{array}{c}\mathrm{WP} \\
\mathrm{kg} \mathrm{m}^{-3}\end{array}$ \\
\hline $\mathrm{T}_{1}-100$ & 108 & $15.0 \mathrm{a}$ & 307 & 355 & 3.3 & 48.9 & 42.3 \\
\hline $\mathrm{T}_{2}-80-0$ & 108 & $13.8 \mathrm{bc}$ & 245 & 283 & 2.6 & 56.3 & 48.8 \\
\hline $\mathrm{T}_{3}-80-1$ & 108 & $13.2 \mathrm{~d}$ & 256 & 295 & 2.7 & 51.6 & 44.7 \\
\hline $\mathrm{T}_{4}-80-2$ & 108 & $14.2 \mathrm{~b}$ & 259 & 299 & 2.8 & 54.8 & 47.5 \\
\hline $\mathrm{T}_{5}-80-3$ & 108 & $14.6 \mathrm{ab}$ & 269 & 309 & 2.9 & 54.3 & 47.2 \\
\hline $\mathrm{T}_{6}-80-4$ & 108 & $13.5 \mathrm{~cd}$ & 260 & 300 & 2.8 & 51.9 & 45 \\
\hline $\mathrm{T}_{7}-60-0$ & 108 & $11.4 \mathrm{f}$ & 184 & 213 & 2 & 62 & 53.5 \\
\hline $\mathrm{T}_{8}-60-1$ & 108 & $11.7 \mathrm{f}$ & 204 & 236 & 2.2 & 57.4 & 49.6 \\
\hline $\mathrm{T}_{9}-60-2$ & 108 & $12.4 \mathrm{e}$ & 210 & 243 & 2.3 & 59 & 51 \\
\hline $\mathrm{T}_{10}-60-3$ & 108 & $12.7 \mathrm{e}$ & 232 & 267 & 2.5 & 54.7 & 47.6 \\
\hline $\mathrm{T}_{11}-60-4$ & 108 & $11.5 \mathrm{f}$ & 213 & 246 & 2.3 & 54 & 46.7 \\
\hline $\mathrm{T}_{12}-40$ & 108 & $9.1 \mathrm{~g}$ & 123 & 147 & 1.4 & 74 & 61.9 \\
\hline $\mathrm{T}_{13-} \mathrm{Trad}$ & 108 & $14.2 \mathrm{~b}$ & 307 & 722 & 6.7 & 46.3 & 19.7 \\
\hline
\end{tabular}


treatment $T_{1}-100\left(15.0 \mathrm{~kg} / \mathrm{m}^{3}\right)$ and the lowest yield was in the treatment $T_{12}-40$ $\left(9.1 \mathrm{~kg} / \mathrm{m}^{3}\right)$. The traditional treatment was recorded to be lower than $\mathrm{T}_{1}-100$ and higher than other treatments [7]. A polynomial functions was fitted between (Y) and (AW) for different seasons (Fig. 1). According to the mathematical analysis of the crop water production function $(\mathrm{CWPF})$, the predicted maximum yields were $19.49,15.18$, and $15.07 \mathrm{~kg} / \mathrm{m}^{2}$ and the corresponding calculated applied water was 600, 630, and $568 \mathrm{~mm}$ for summer, fall, and winter respectively (Table 2). These results were in agreement with those reported by [12, 13], however Mao et al. [7] reported a polynomials relationship between ET and yield. In this study, treatment $T_{1}-100$ had the highest yield and treatments $T_{3}, 4,5$, $6^{-}-80$ and $\mathrm{T}_{12}-40$ gave fairly good marketable yield with economically saving water, fertilizers and pesticide. The result also indicated that the water productivity (WP) increased with decrease the amount of applied water, the WP were 42.3 and $61.9 \mathrm{kgm}^{-3}$ for $\mathrm{T}_{1}-100$ andT $\mathrm{T}_{12}-40$, respectively. However the traditional irrigation treatment gets the lowest value of WP $\left(19.7 \mathrm{~kg} \mathrm{~m}^{-3}\right)$. Although lack of irrigation as in treatments $T_{12}-40$ led to very high water productivity however it also led to poor quantity and quality of yield.

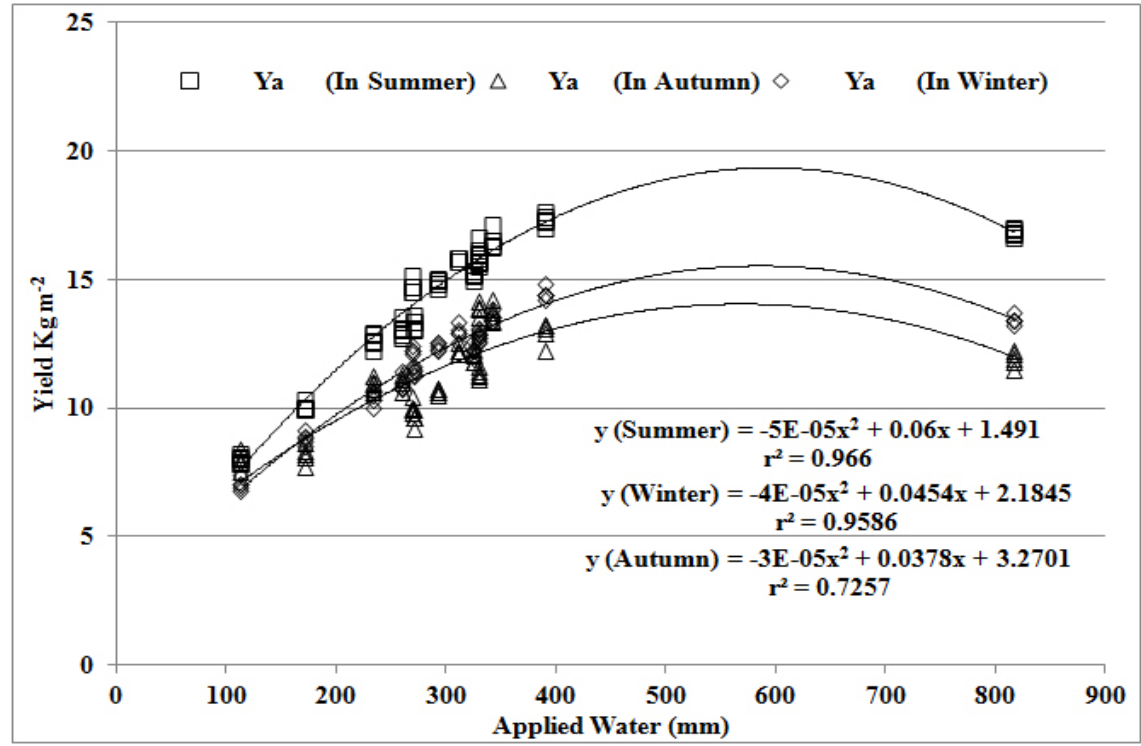

Figure 1: The relationship between marketable total cucumber yield and applied water at different seasons.

The results also indicated that the deficit irrigation at $80 \%$ of ETc was more efficient in saving irrigation water with a good marketable yield compare to traditional irrigation and 100\% ETc. Moreover the deficit drip irrigation helps in rationalization and preventing excessive use of pesticides and fertilizers consequently reduce environmental pollution and economic depletion. 
Table 2: Cucumber water production function according to applied irrigation water

\begin{tabular}{ccccc}
\hline Season & Crop water production function & $\mathbf{r}^{2}$ & $\begin{array}{c}\text { Maximum } \\
\text { yield } \\
\left(\mathrm{Kgm}^{-2}\right)\end{array}$ & $\begin{array}{c}\text { Applied } \\
\text { water } \\
(\mathrm{mm})\end{array}$ \\
Summer & $\mathrm{Y}=-5 \mathrm{E}-05(\mathrm{AW})^{2}+0.060(\mathrm{AW})$ & 0.966 & 19.49 & 600 \\
Winter & $\mathrm{Y}=\begin{array}{c}+4 \mathrm{E}-05(\mathrm{AW})^{2}+0.0454 \\
(\mathrm{AW})+2.1845\end{array}$ & 0.9586 & 15.07 & 568 \\
Autumn & $\mathrm{Y}=-3 \mathrm{E}-05(\mathrm{AW})^{2}+0.0378(\mathrm{AW})$ & 0.7257 & 15.18 & 630 \\
\hline
\end{tabular}

\section{Conclusions}

The management of water in xeric regime and under water scarcity includes multiple policies. In general, policies should aim at reducing the non-beneficial water uses, particularly those corresponding to water consumption and to the non-reusable fraction of the diverted water. However, fully exploring these concepts, mainly for farmers at field scales, requires appropriate procedures to be developed. Reduced water demand can be achieved by adopting improved farm, irrigation systems, and deficit irrigation.

\section{References}

[1] Topcu, S., Kirda, C., Dasgan, Y., Kaman, H., Cetin, M., Yazici, A., Bacon, M.A., 2007. Yield response and N-fertiliser recovery of tomato grown under deficit irrigation. European Journal of Agronomy. 26, pp. 64-70.

[2] Patanè, C., Cosentino, S.L., 2009.Effects of soil water deficit on yield and quality of processing tomato under a Mediterranean climate. Agricultural Water Management, 97 (1), pp. 131-138.

[3] Kirda, C., M. Cetin, Y. Dasgan, S. Topcu, H. Kaman, B. Ekici, M. R. Derici, Ozguven, A. I., 2004. Yield response of greenhouse grown tomato to partial root drying and conventional deficit irrigation. Agricultural Water Management. 69 (3), pp. 191-201.

[4] Pereira, L.S., Oweis, T., Zairi, A., 2002. Irrigation water management under water scarcity. Agric. Water Manage. 57, pp. 175-206.

[5] Agele, S.O., Iremiren, G.O., Ojeniyi, S.O., 2011.Evapotranspiration, Water use efficiency and yield of rainfed and irrigated tomato. Int. J. Agric. Biol. 13, pp. 469-476.

[6] Amer, K. H, Sally, A. M., Jerry, L. H., 2009. Effect of Deficit Irrigation and Fertilization on Cucumber. Agronomy Journal. 101, pp. 1556-1564. 
[7] Mao, X., Liu, M, Wang, X., Hou, C. Z., Shi, J., 2003. Effects of deficit irrigation on yield and water use of greenhouse grown cucumber in the North China Plain. Agricultural Water Management. 61 (3), pp. 219-228. Doi:10.1016/S0378-3774(03)00022-2.

[8] Page, A.L., Miller, R.B., Keeney, D.R., 1982. Methods of soil analysis part 2. Chemical and microbiological properties. Second Edition.

[9] Ali, M.A., Hoque, M.R., Hassan, A.A., Khair A., 2007. Effects of deficit irrigation on yield, water productivity, and economic. Agric. Water Manag. 92, pp. 151-161. doi:10.1016/j.agwat.2007.05.010

[10] Oweis, T., Hachum, A., 2004.Water harvesting and supplemental irrigation for improved water productivity of dry farming system in west Asia and North Africa. In Proceeding of the 4th Int. Crop Sci. Congress, held at Brisbane, on the theme "Crop Science for Diversified planet".

[11] Zhang, Y., Kendy, E., Qiang, Y., Changming, L., Yanjun, S., Hongyong, S., 2004. Effect of soil water deficit on evapotranspiration, crop yield, and water use efficiency in the North China Plain. Agric. Water Manage. 64, pp. $107-122$.

[12] Al-Harbi, A.R., Al-Omran, A.M., El-Adgham, F.I., 2008. Effect of drip Irrigation Levels and Emitters Depth on (Abelmoschusesculentus) Growth. J. of Applied Sci., 8, pp. 2764-2769.

[13] Zhang, H., Oweis, T., 1999.Water-yield relations and optimal irrigation scheduling of wheat in the Mediterranean region. Agricultural Water Management. 38, pp. 195-211. 